\title{
Denial and Distancing in Discourses of Development: shadow of the 'Third World' in New Zealand
}

\author{
PRIYA A KURIAN \& DEBASHISH MUNSHI
}

\begin{abstract}
Anxieties about development in New Zealand show up in a deeprooted fear of the 'Third World' in the country. We examine how the term 'Third World' is deployed in media discourses in economic, social and environmental contexts and how this deployment results in a 'discursive distancing' from anything associaled with the 'Third World'. Such distancing demonstrates a fragile national identity that struggles with the contradictions between the nation's desire to be part of the 'First World' of global capitalism and the growing disparities in health and wealth within it. The shadow of the 'Third World' prevents New Zealand from confronting the realities of its own inequities, which in turn comes in the way of a sound development agenda.
\end{abstract}

we in New Zealand persist in seeking the magic elixir that will propel us into the economic top league.

The search for rapid economic development that yields prosperity, while ensuring environmental, social and cultural protection, is an elusive goal sought by governments around the world. New Zealand's search for 'the magic elixir' that delivers development has been marked by massive shifts in policy that has seen it move from a welfare state to a neoliberal competition state since the 1980s. Even after three decades of privatisation, corporatisation and economic liberalisation, New Zealand still sees itself teetering on the edges of 'First World' status. In terms of economic productivity, savings, investment, low national debt and other measures of economic success, there seems little movement up the ladder of the Organisation of Economic Cooperation and Development (OECD). What is striking is that this material context of what is viewed as inadequate development in New Zealand reffects a "discursive phobia of the Third World'. New Zealand politicians, policy makers, business executives, media commentators and the public share an underlying anxiety about the country being mistaken for part of the 
undesirable realm of the 'Third World', which would thereby jeopardise the claim to a First World national identity.

Development as a construct in New Zealand is, thus, marked by discourses that juxtapose its First World status with a deeply pejorative construction of what it is to be 'Third World'. Yet what do these discourses of the 'Third World' tell us about the development project in New Zealand? This article explores this question through an analysis of these discourses in a variety of economic, social and environmental contexts as articulated in the news media. We argue that New Zealand's desire to distance itself from a 'Third World' label stems from a deep-rooted anxiety to deny its racially marked past, and to see itself (as well as to be seen by the outside world) as a part of the capitalist, neoliberal and modern 'First World'. We explore how this anxiety underpins discourses of both development and identity in this politically young country in the South Pacific shaped by a dominant style of governance and polity set up by colonial settlers. ${ }^{3}$

We begin with a discussion of the research methodology, followed by a look at the development landscape of New Zealand to show how it is framed by a modernist vision. We then examine the ways in which the discourses of development and identity are intertwined and move on to an analysis of how the term 'Third World' is deployed by various actors via the news media in New Zealand, and the implications of this for the development project in New Zealand.

\section{Methodology}

We undertook an analysis of news reports and opinion pieces, including editorials and letters to the editor, which appeared in Newztext Plus, a database of New Zealand news media, for a five-year period spanning 200611. Newztext Plus indexes 22 daily newspapers, a weekly newspaper (Sunday Star Times), two magazines (the National Business Review and the Independent Financial Weekly), and three newswires, namely, Radio New Zealand, Scoop.co.nz, and BusinessDesk. The newspapers include the country's largest English daily, the New Zealand Herald, as well as various regional newspapers in both the North Island and South Island, thus ensuring a national coverage for our analysis. We searched for all published material in the database that used the term 'Third World' between 2006 and 2011. This period marks the last two and a half years of the Fifth Labour Government's tenure, ending in 2008, and the first two and a half years of the new National-led government. Thus we were able to examine whether changes in government and policies had any kind of impact on the deployment of the 'Third World' construct in the news media.

We made sure that syndicated repetitions of the same article were deleted from the corpus, leaving us with a total of 521 pieces. We read through all the news reports, articles, commentaries and letters to the editors of newspapers and noted the context in which the term 'Third World' was used. Our decision to include Letters to the Editor in the corpus was guided by the fact that our study was not a content analysis of media reports but rather a 
critical analysis of a mediatised social construction of the 'Third World' in New Zealand. Letters to the editor are an important part of the public sphere, ${ }^{4}$ and are widely followed by newspaper readers. ${ }^{5}$ Indeed, as Young says, "letters are unique in the news media landscape--sites of unpredictability where standard media norms are weakest and non-journalistic narratives have an opportunity to leak in'. 6 We categorised the corpus thematically according to the issue being discussed. This resulted in creating the following categories: 'economy', including infrastructure development and public services; 'society', including indigenous and immigration issues, healih, education, poverty, and crime; and 'environment'. Our focus was on unpacking the discourses around the use of the term 'Third World" to explore their implications for the development project in New Zealand.

We want to emphasise here that we do not assume that the pejorative and often racist construction of the notion of the Third World is reflective of any overwhelming dislike or hatred towards the peoples from the Third World in New Zealand. The country is rightly viewed as a largely tolerant society that has rapidly become socially, ethnically and culturally diverse in the past three decades. Yet, as is perhaps true for all white-dominated settler societies, there is a dominant discourse that seeks to cement a national identity by, consciously or subconsciously, valorising whiteness; this dominant discourse in turn has profound implications for the development project in the country. ${ }^{7}$

\section{The 'Third World' in development}

Making sense of the ubiquitous use of the 'Third World' in public discourses in New Zealand requires a brief tour of the origins, contentious meanings and varied applications of the term. As is now well documented, the term 'Third World' gained currency in the mid-1950s with an ambitious grouping of newly independent states committed to rising from the shackles of colonialism to a brave new world of freedom, liberty and poverty alleviation. ${ }^{8}$ Since then the death of the term 'Third World' has been proclaimed with regular frequency by scholars who despair of its utility or see it as irrelevant in the face of forces of globalisation, US imperialism and the fracturing of the hope that the term once conjured. ${ }^{9}$ Yet the term continues to circulate in popular, political and academic discourses, ranging across a continuum from representing a political project of unity and hope for marginalised peoples everywhere to a positivist, descriptive term of placement in a hierarchy of three worlds, to the pejorative use that is seen in New Zealand.

The origin of the notion of three worlds lies in the modernisation discourse that shaped development theory and practice after World War II. Modernisation theory, which sought to identify social and institutional factors that facilitate development, perceived development as a linear, unidirectional, evolutionary process of change whereby societies evolved in several stages from a pre-modern stage to a modern one. The concept of development as economic modernisation by nations was also linked to the 
anti-colonial struggle. ${ }^{10}$ According to Wallerstein, for example, national development was at the core of the otherwise clashing ideologies of both Leninism and Wilsonianism. ${ }^{11}$ In chronological terms modernisation was a process of the Third World (situated in the 'primitive past') catching up with the First World (already always deemed the 'future perfect'). ${ }^{12}$ The primacy of the modernisation project and the idea of the three worlds in the period after World War II, framed as it was by the Cold War, depicted the struggle between the capitalist First World and the communist Second World for hegemony over the newly independent countries of the Third World. ${ }^{13}$ Dirlik cites Pletsch, who offers a detailed analysis of the 'logic of the production of the Third World':

The third world is the world of tradition, culture, religion, irrationality, underdevelopment, overpopulation, political chaos, and so on. The second world is modern, technologically sophisticated, rational to a degree, but authoritarian (or totalitarian) and repressive, and ultimately inefficient and impoverished by contamination with ideological preconceptions and burdened with an ideologically motivated socialist elite. The first world is purely modern, a haven of science and utilitarian decision making, technological, efficient, democratic, free-in short, a natural society unfettered by religion or ideology. ${ }^{14}$

Yet, simultaneously, this modernist construct of the 'Third World' was embraced by 'radical advocates of liberation from Euro-American colonialism and hegemony who saw in it both a mobilising idea to complete the tasks of decolonisation, and a means of reorganising global relationships'. ${ }^{15}$ Although the post-cold war era has seen the gradual disintegration of the notion of three worlds, 21st century processes of 'Capitalics' - a capitalismdriven politics - has entrenched the ideological divisions between a capitalrich First World and a labour-rich Third World. ${ }^{16}$ This division is particularly useful for "key Western players' to "homogenise" the experience of the very particularity of social formations on the so-called Periphery...to control them in the name of a universalising "modernisation theory". "It is also a device to gloss over the failings of market-driven global capitalism to tackle global and domestic problems.

The ideological division between groups of nations is a major part of struggles over national identity. Our analysis of the ways in which the term 'Third World' is deployed in New Zealand shows how a discursive positioning of the 'Third World' in deliberately inferior terms serves as a mechanism to reinforce the idea of an imagined superiority of the 'First World'. As Escobar argues, 'The deployment of this discourse in a world system in which the West has a certain dominance over the Third World has profound political, economic, and cultural effects' ${ }^{18}$ The very identity of New Zealand as a 'First World' nation, therefore, depends on casting itself not as what it is but as what it is not-a part of the 'Third World'. 19 In rejecting any association, implicit or otherwise, with the 'Third World', the dominant discourse in New Zealand denies the anti-colonial understandings of the term 'Third World' so as to strengthen its identity as a 'purely modern' 
First World nation, marked as much by science, technology and efficiency as by a largely white settler society.

\section{The 'Third World' as an 'Other'}

The desire to be part of the First World moulds the nature of development in New Zealand. Rather than drawing on the experiences of the 'Third World' to reflect on its own colonial structures of policy making and growing economic disparities in health, wealth and well-being, the dominant discourses of development focus attention instead on what is perceived to be a 'First World' approach to development. As Ganesh and Zorn show in the context of discourses around the growth of broadband in the country, the notion of 'competition' takes on a 'quasi-sacred hue' linked as it is to the idea of competing successfully in the OECD and 'avoid[ing] plunging into Third World status' ${ }^{20}$ Equally notable is the fact that the deployment of the 'Third World' construct is spread across the political ideological spectrum, although with markedly different intentions at work, including in ways laced with racism. These themes are evident across discussions on the economy, society and the environment. We begin our analysis by scrutinising discourses on the economy.

\section{Economy}

Our analysis shows that concern for the economy, including infrastructure and public services, accounts for over hall the media articles and letters that invoke the Third World. The conflation of development with economic growth, a dominant discourse globally, is accompanied in New Zealand with an acute anxiety about the country's economic status, which manifests in a number of ways, as we discuss below.

Depending on their political affiliations, people in New Zealand are split on the direction of the nation's economic policies. Supporters of the centreright National Party, which currently heads the country's coalition government, back Prime Minister John Key's strategies of lower personal taxes combined with proposed cuts to schemes targeting lower income families and individuals, such as Working For Families and Student Loans, as well as a partial sale of state assets to encourage 'faster wage growth and more jobs'. ${ }^{21}$ A lower personal tax base was, in fact, a major election issue for the National Party in the 2008 general elections. In echoing this line of thought, a media commentator remarked before the election:

Labour likes to point to the healthy state of Crown finances as if this were proof of a strong economy when in fact all it shows is that people have been paying a lot of tax. Other key economic indicators productivity, per capita GDP, average incomes, the overseas deficit--are dismal and getting worse, relative to other countries. New Zealand is slipping down the OECD rankings and being overtaken by upwardly mobile countries that we once patronisingly looked down on as Third World. ${ }^{22}$ 
A member of the public seemed to agree with this assessment of the Labour government:

It is time to stop the slide down the slippery slope to Third World status that looms ever closer. Now is the time for a new broom to sweep out the bureaucratic overload. The most effective way to have a growing economy is with a small government and low taxes. ${ }^{23}$

The antipathy to both higher taxes and government bureaucracies, characteristic of neoliberal ideology, is evident here. In both instances the 'Third World' is invoked as a looming threat that requires action from the state. Also significant in the first quote is a reference to OECD rankings, a long-standing concern for commentators and politicians. Indeed, it is not just with regard to the economy that we find the frequent discursive references to the OECD. It appears also in areas as diverse as education, ${ }^{24}$ children's health, ${ }^{25}$ and the death toll on roads. ${ }^{26}$ In each instance, the OECD serves as an external reference point at the positive high end of a continuum, while the 'Third World' stands at the negative bottom end. ${ }^{27}$

It is noteworthy also that the bogey of the 'Third World' is invoked across the political spectrum, including from many who are opposed to the National Party's policies, such as left-leaning trade unions. The government's huge borrowing to keep the economy ticking had critics worried that the nation would become a part of the 'Third World' if such tendencies were not curbed. Let's just take two examples of the 81 references to the 'Third World' economy and 220 references to 'Third World' infrastructure we found in our sample:

How coming generations are going to pay this lot back doesn't bear thinking about. Running continuous deficits is making the grandkids pick up the tab so that today's voters have their cake and eat it too. Many won't. The smart will leave, and our avoidable descent into Third World squalor will continue. ${ }^{28}$

Is New Zealand on the road to becoming a Third World country? That might seem a strange question, but I believe we are becoming so reliant on borrowing that our economy is almost operating on a Third World basis already. ${ }^{29}$

The 'road' and the 'slide' to the 'squalor' of the 'Third World', described by members of the public in the above quotes, is echoed by a politician who stated that, unless the country started "planning our economy, we face dire circumstances for generations ahead. We cannot afford to keep sliding to the Third World. ${ }^{30}$

The implicit fear of the 'Third World' is spread through the five-year period of our sample regardless of whether the government was led by the Labour Party or the National Party. In a letter to the editor of a local newspaper, a resident of Manawatu declared in 2007: 'Third World status is a very likely conclusion if we have another three years of Labour's mismanagement'.31 Four years later a media professional derided the 
National government for its decision to wind up the public television channel TVNZ7 and said that this decision "puts us well behind every other developed country in the world--and many Third World countries'. 32

The idea of the 'Third World' as an economic basket-case and a place of poverty and filth smacks of an ideology that situates the 'Third World' as fundamentally inferior in all respects to New Zealand. A leftist tradeunionist, media commentator and politician picked up on how these discourses sometimes become explicitly raced by saying:

We delude ourselves, believing we are a First World developed country when it must be becoming increasing[ly] clear we are on track to be the first "white' country to slide into the Third World category. ${ }^{33}$

The conflation of 'white' with the 'First World' is indeed part of a dominant discourse that the politician appears to refer to. That there is an element of race hidden under the layer of the term 'Third World' also comes through in studies on discourses around immigration, for example. ${ }^{34}$

Overall four strands are woven into the use of the Third World in the economic discourse of development: the use of the OECD as an external aspirational reference point juxtaposed against the nadir of the Third World; the ubiquitous deployment of the term across the political spectrum; the notion of the Third World as a looming threat; and the raced nature of the use of the term. This interplay between economic issues of development and the four strands, especially issues of race and ethnicity, brings us to an analysis of discourses around society that reveal another dimension of the anxiety around the 'Third World'.

\section{Society}

If development is measured in terms of 'well-being', as per the focus of the United Nations Development Programme's Human Development Index (HDI), then it would entail taking account of a society's performance on access to health, education, nutrition, as well as on class and gender equality. Although New Zealand ranks high on many measures of the HDI, a closer look at the statistics by ethnicity, especially those for Maori, reveals a more troubling picture. Our analysis of the mediated discourses around social development demonstrates a concerted attempt to distance New Zealand from the feared status of the Third World, while simultaneously denying the causes of such social disparities.

Although New Zealand prides itself on its bicultural character and on the principles of the Treaty of Waitangi signed between Maori chiefs and the British Crown in 1840 , development indices in the country are still stacked against the original settlers of the land--Maori, who comprise $14 \%$ of the country's population. In $200624 \%$ of Maori lived in the most socioeconomically deprived areas (compared with $7 \%$ of non-Maori), while only $3 \%$ of Maori lived in the least deprived areas (compared with $12 \%$ of nonMaori). Maori life expectancy at birth was at least eight years less than that 
for non-Maori for both sexes. Maori also have higher rates across many health conditions and chronic diseases, including cancer, diabetes, cardiovascular disease and asthma. ${ }^{35}$

Despite these stark disparities, any attempt by the state to foster development that benefits Maori is immediately seen by a dominant section of the population to be coming at the cost of 'national' development. Rightwing politicians such as the former leader of the National Party and later leader of the ACT Party, Don Brash, have a record of Maori-baiting under the guise of 'one law for all'. ${ }^{36}$ However, significant sections of the population, too, resent money being spent on Maori welfare on the grounds that it reduces the rest of the country to a 'Third World' status:

We find billions of dollars to hand out to a small sector of the population to appease a historical document. Yet clearly our nation is barely holding together with an archaic infrastructure that is teetering at Third World standards. ${ }^{37}$

Prime Minister Helen Clark and [Finance Minister] Michael Cullen have taken taxpayers' money and paid the Maori again for land and then given the trees and buildings which we the taxpayer paid for and created and by doing so demolished hospital standards to Third World. ${ }^{38}$

This preoccupation with a fear of the 'Third World' masks the reality of the state of impoverishment in the country. Rather than acknowledging the flaws within, there is a concerted effort to deny the systemic failures that have steadily increased the gap between the haves and have-nots in the country. This denial is expressed by naming the ills of the country as something foreign and alien - the 'Third World'. When politicians, community leaders and people in civic life lament the growing poverty, joblessness, social insecurities and health-related problems, they do so by labelling these as 'Third World' problems. This 'othering' of the 'Third World' in New Zealand has weakened its diversity profile, creating a disjuncture between its professed development goals as a member of the global economy and its implicit desire to maintain a distinct identity that is officially bicultural but structurally monocultural. The nation's struggles with a coherent immigration policy bear testimony to this disjuncture.

One of the distinctive features about discussions on immigration in New Zealand is the easy slippage between the terms Asians and immigrants as if they are synonymous with each other. ${ }^{39}$ In such a context 'A recent English immigrant is not seen as an immigrant, but a second or third generation New Zealander of Chinese or Indian origin continues to be viewed as one'. ${ }^{40}$ This perception is so widespread that people who are non-white, and thus ostensibly from what is seen to be the 'Third World', face the brunt of deeprooted institutional prejudice and are hugely disadvantaged in the job market. ${ }^{41}$ Significant anti-Asian feelings in the country often come out in the open quite freely:

Religious and racial hatreds cannot be fostered, promoted or fomented when huge expanses of ocean separate the differences. This is why we are burdened 


\section{DEVELOPMENT PERSPECTIVES FROM THE ANTTPODES}

with a Third World immigration policy. With the current example of a NZ housing shortage and inadequate infrastructures such as roads, public transport, health care, education, law and order, prisons, electricity supply and etc, surely now is the time to call for a moratorium on immigrants from Asia or any Third World nations before our country becomes as bad as theirs -... filthy, corrupt, over-crowded and totalitarian. ${ }^{42}$

It's inorganic collection time in my neighbourhood... Taking an evening stroll through the rat infested mattresses, sharp springs and broken glass, new immigrants must think they took a wrong turn in the Pacific and landed in a Third World refugee camp. ${ }^{43}$

In terms of development 'Third Worldisation' is an issue 'where race appears to demarcate the status of being "developed" or not ${ }^{44}$ New Zealand clearly needs its immigrants to drive its development engine. However, its obsession with a First World identity spills over into rejecting 'Other' immigrants, however highly skilled, who seem to visibly represent the 'Third World'. This in turn tends to restrict the possibilities of the very development that is aspired to by the country.

What is noteworthy is that the raced discourses against 'visible migrants' also often get directed at Maori. For example, John Banks, a government minister and former mayor of Auckland, is reported as describing Maori as "dragging New Zealand into the Third World as "natives who have nothing better to do than wave spears on television". ${ }^{45}$ Other articles and letters refer to Maori as raising their children in 'Third World conditions', ${ }^{46}$ living in 'Third World slums, ${ }^{47}$ and indulging in 'Third World practices'. ${ }^{48}$ Also striking is the slippage between race, criminality and the 'Third World' which becomes clear in the following quote:

Tariana Turia [co-leader of the Maori Party], in a recent television debate, stated: 'This country is getting browner by the day, isn't it wonderful.' Perhaps she could explain just what is so "wonderful" about it? Does she think a commensurately higher rate of criminality and welfare dependency is "wonderful"? For some time we have witnessed economics commentators expressing some dismay at our slide down the OECD rankings, even portentous mumblings about our emerging 'Third-World economy'. We do not have to look far for the reason, do we Tariana? ${ }^{49}$

The development project in the country is thus muddied not only by its indecisiveness about its identity as a bicultural or multicultural nation, but also by the dialectical challenges posed by its assertions of an independent identity as a nation in the Pacific vis-à-vis its hard-to-shake-off identity as a nation settled by Europeans. This raises a key question on how notions of identity intersect with development in New Zealand.

A trawl through New Zealand's current socioeconomic indicators reveals the serious challenges to achieving 'good development', measured by some notion of the well-being of all citizens. In the last decades of the 20th century New Zealand has had the sharpest decline in income and wealth equality in the OECD. In 2006 07230000 children, comprising $22 \%$ of all children, were 
living in poverty. ${ }^{50}$ In 2011 New Zealand was ranked 28 th out of 30 assessed OECD countries on child outcomes, based on a comparison of a number of areas, including infant mortality, deprivation and education. ${ }^{51}$ It has one of the highest rates of maternal mortality, ranking 20 out of 22 assessed OECD nations. ${ }^{52}$ New Zealand children also have higher rates of preventable illness and deaths from injuries than children in almost any other OECD country. ${ }^{53}$

If we take the issue of health, the decline in New Zealand's health profile has more to do with misplaced development planning than with the advent of 'Third World diseases'. Yet reference to this mythical category of diseases is ubiquitous. In an address to the Association of Salaried Medical Specialists, a doctor said that 'New Zealand has Third World rates of pneumonia, skin infections and rheumatic fever, which should be shameful' ${ }^{54}$ Similarly Green Party co-leader, Meteirei Turei, said in her address to Parliament that 'We have Third World rates of rheumatic fever that comes from overcrowding and that cost our health system $\$ 10$ million every year'. ${ }^{55}$ There were as many as 104 references to 'Third World' in the reporting on health issues in our five-year sample. The most provocative way to highlight health issues was to describe it in 'Third World' terms:

Per capita, more Kiwi children are being killed (two a week), or admitted to hospital (9880 a year) as a result of accidents than in any other country in the OECD. The lack of national standards for dealing with young trauma victims is costing lives. Third World-type diseases, associated with poverty and overcrowding, are placing a strain on some of our hospitals, and this is also unacceptable. ${ }^{56}$

The availability of radiation treatment for cancer patients approaches Third World standards. ${ }^{57}$

My 84-year-old mother was admitted at $7 \mathrm{pm}$ on Thursday, September 4 , with a broken hip and was, by Saturday, still waiting for surgery. No one could even tell me when she might have the surgery she needs. This is Third World medicine and is simply not acceptable. ${ }^{58}$

The use of the term 'Third World' in societal discourses on development reveals, at one level, a refusal by some to recognise the negative impacts of uneven development on the most marginal sections of society, including Maori, ethnic minorities, and children. This denial of impoverishment is evident in dubbing social ills as something foreign and alien. At the same time, there is a discursive slippage between race and criminality that includes within its sweep both Maori and non-white immigrants. At another level, however, the term is used not necessarily to deny the immensity of the problems of inequality but as a way to spur action to address these problems. A similar ambiguity is evident in the discourses around environmental protection.

\section{Environment}

The recurrence of the 'Third World' metaphor continues in discussions around the environment as well. Once again the term is bandied about 
regardless of political affiliation. On the one hand, those sympathetic to a Green agenda see the economic push to loosen environmental safeguards as well as the absence of adequate regulatory checks on dumping of wastes as an attempt to let the country slip into 'Third World' conditions:

[The Don Brash-led Productivity Taskforce Report's suggestion that] we should do away with the Resource Management Act...is just ridiculous. It would turn us into a Third World country and remove our key competitive advantage: the quality of our environment. ${ }^{59}$

When $6000 \mathrm{ku} \mathrm{m}$ of raw sewage pours into our beautiful harbour, it is not a spill, it is a disaster. reminiscent of the Third World, and it's the second time this has occurred in one month. ${ }^{60}$

On the other hand, those who support economic growth and increasing the nation's wealth argue that efforts to protect the environment would have an adverse impact on the First World living standards in the country. The following quote illustrates this concern. Referring to Green Party suggestions that the agriculture sector should be included in the Emissions Trading Scheme much sooner, the chair of Federated Farmers, Lachlan McKenzie, stated:

The question 1 have for the Russel Normans [Green Party co-leader] of the world is would they rather have a First World living standard or do they want a Third World living standard? ${ }^{61}$

Another theme to emerge in our analysis of environment-related issues is one that saw rejecting new technologies, such as biotechnology, as resulting in New Zealand succumbing to a 'Third World status':

Crop and Food scientist Dr Tony Conner warned the audience at a biotechnology workshop in Hamilton earlier this month that New Zealand agriculture risked falling to 'Third World status' if it did not accept commercialisation of GE crops. ${ }^{62}$

In addition, the commentary on environmental issues, reminiscent of the sentiments expressed on economic and social issues, associates the Third World with chaotic sprawl and filthy, bug-ridden waterways. This view deems anything ugly and dirty to be suggestive of the Third World as we see below:

Wind-blown rubbish from the Timaru landfill at Redruth continues to end up in Saltwater Creek and the Otipua Wetlands. Rowing coach Dean Milne is one of those irritated about the ongoing presence of litter. With plastic bags pressed against the netting and pungent landfill stench wafting in a northerly breeze, this section of the Saltwater Creek walkway gave him a feeling of Third World poverty. ${ }^{63}$

Other stories refer to 'Third World building, really shantytown stuff, ${ }^{64}$ beaches once golden and beautiful, that are now 'messy' and 'gone Third 
World', ${ }^{65}$ and 'rubbish strewn along the road' as in a 'Third World country'. ${ }^{66}$ This portrayal of dirt, wastes and smells is juxtaposed implicitly against the image of a modern nation that must by definition be clean and beautiful.

New Zealand's 'clean, green image' is one that is not only intertwined with national identity, as we discuss later, but has also been marketed vigorously to gain a competitive edge in the global market. A report commissioned by the Ministry for the Environment found that 'this image was worth about NZ\$530 million to the tourism sector and NZ\$938 million to the economy as a whole'. ${ }^{67}$ The image, the focus of a successful multi-million dollar advertising campaign promoting the slogan ' $100 \%$ Pure New Zealand' (replaced most recently with ' $100 \%$ Pure You') ${ }^{68}$ has been under increasing attack. The lifting of the moratorium on genetic engineering field experiments in 2002, the declining water quality of rivers, the recent proposal (now recanted) to open up conservation lands to mining, and the on-going effort to resume coal mining on an unprecedented scale demonstrate the shaky ground on which the 'clean, green image' rests. Environmental scientist Mike Joy describes New Zealand as 'delusional about how green and clean we are', and asks:

Why is it that New Zealanders are not outraged that we have slipped so far environmentally in such a short time? Surely this apathy reflects the power of the business lobby to keep the ecological truth hidden and to convince us that the economy is of prime importance. It appears this odd belief, that the economy is more important than the environment, has pervaded most government economic and social policy. ${ }^{69}$

Contrast Joy's words with an Editorial from the New Zealand Herald that firmly supports the ' $100 \%$ Pure' slogan as being true to reality:

It is true that New Zealand does not have to try very hard to be clean, green, fresh and wholesome. With only 4 million people in an area as large as the United Kingdom, and lying in temperate latitudes, surrounded by oceans, exposed to the trade winds, we are assured of fresh air, frequent blue skies, bright light, plenty of rain, abundant vegetation and wide open spaces. Environmentalists are a long way from convincing the country that rural waterways are degraded in ways that really matter. They earn their cause no credit by invoking tourism's marketing brand. It is simple, innocent, evocative and-unless we are to be impossibly pure it is true. ${ }^{70}$

What is evident in our study is that the business and agricultural lobby, and their supporters, as well as environmentalists who seek better environmental protection, invoke the 'Third World' to argue their case. Yet, as is clear from the New Zealand Herald editorial, the obvious physical beauty of the country so successfully masks the realities of deteriorating environmental conditions that it renders such invocations futile, reflective yet again of a state of denial. 


\section{Discursive distancing in identity construction}

Our analysis of media discourses reveals the wide use of the term 'Third World' across a range of sites, including the economy, society and the environment. These findings demonstrate that New Zealand's anxieties about its First World status, reflected in the discursive attempts to demarcate itself from the 'Third World', are intertwined with a fragile national identity. ${ }^{71}$ The upheavals of the neoliberal policy reforms, which saw, among other things, the opening up of immigration policy from an almost entirely "white New Zealand' policy to one that emphasised the skills of prospective migrants, triggered what may be described as a social panic about national identity and New Zealand's place in the world. ${ }^{72}$ It is no doubt recognition of this panic that led recent central governments to actively promote the country's 'unique' cultural identity. The Helen Clark government's decision to promote national identity as a key goal for the country came about in the face of the 'social dislocation and an erosion of shared values and social cohesion' caused by the hyper-neoliberal economic transformation from the mid1980 s. $^{73}$

Indeed, the construction of a cultural or national identity "can be seen as part of what Hall, following Antonio Gramsci, might call a "hegemonic project" in which preferred definitions of problems, solutions and goals are presented as a shared, national common sense. ${ }^{74}$ The need to gain and retain a competitive edge in the global market is part of this hegemonic project and, as True and Gao show, the 'national narrative' around New Zealand's identity has in recent years been reinvented to serve the ends of global economic success'. ${ }^{75}$ This process of identity building "emerged, not as a form of resistance or opposition to the power of global capital, but instead as a way to capture the attention of powerful investors, talented people, foreign tourists and consumers. ${ }^{76}$ This is most evident in the way in which the country has capitalised on its 'clean, green and $100 \%$ pure' image.

The focus of this economically oriented image branding is not on the country's heavily polluted rivers, the dumping of sewage into waterways, the loss of biodiversity, or the overuse of synthetic fertilisers, but on its stunning beaches, national parks, mountains and wilderness areas. Critics of the government's inaction on environmental issues also deploy the 'Third World' construct, reflecting an over-riding anxiety about environmental damage that violates their vision of New Zealand.

The dissociation from the 'Third World' is illustrative of a process of discursive distancing ${ }^{77}$ that inhibits the ability to address what are essentially "wicked problems' ${ }^{78}$ The process of discursive distancing results in framing certain problems in terms of a 'Third World' discourse so as to render these problems as 'not ours' and, consequently, prevent an appropriate response. This discursive distancing is driven not merely by an economic imperative; there is a cultural imperative as well which, derived from a kind of cultural nationalism, is based on the experiences of the country's demographic majority. As prominent cultural historian Peter Gibbons says, 'the construction by Pakeha [Europeans] of a New Zealand national identity was not a sign 


\section{DEVELOPMENT PERSPECTIVES FROM THE ANTIPODES}

that the colonisation phase of history was over, but an important part of the on-going (and still uncompleted) processes of colonisation'. ${ }^{79}$ The term 'Third World', therefore, may be seen as a distancing of the country not only from the realities of the present, but also from a past marked by the trauma, cultural decimation and violence experienced by the racially marked first settlers, the Maori.

The phobia of the 'Third World' is, thus, an intrinsic part of the process of identity building in New Zealand. As Skilling comments:

There is nothing neutral or natural about the way in which the nation is represented by various actors. It is not the invention of a national identity from nothing, but a purposeful re-imagining in which some existing markers of identity are emphasised, while others are marginalised. ${ }^{80}$

\section{Identity and development-concluding thoughts}

By examining mediated discourses that represent a wide spectrum of political, social and economic voices, we provide an insight into the complexities of tackling development in a country that finds itself in the midst of acute contradictions: it is economically part of the global North but geographically in the South; it is a member of the rich OECD but has issues of poverty of its own; its overall well-being has historically been linked to the welfare state but its economic agenda is based on dismantling the welfare safety net; it is a postcolonial nation but functions too often as a political and economic colonial power in the region.

It is worth noting that actors of the political centre-right, as well as those occupying the centre-left and green ideological space, use the 'Third World' construct pejoratively to push their own agendas. Those at the right end of the political spectrum push the neoliberal button to seek an unfettered capitalism-driven economic growth that will keep New Zealand in the socalled First World. Those on the left seek state intervention to prevent New Zealand's accelerating descent into the greater income inequality, environmental destruction and poverty that they see as characteristics of the Third World. Both these contradictory impulses shape the contours of a still emergent national identity that is based on being something that is not the Third World.

So how does New Zealand's identity construction process affect the nation's development agenda? A key argument we offer in this paper is that the discursive distancing involved in using the construct 'Third World' to describe economic, social and environmental issues affects decision-making processes by disrupting feedback along those nodes. That this discursive distancing is deployed across the political spectrum of the left, the right and the centre makes it particularly problematic.

The ease and frequency with which the term 'Third World' gets used also entrenches, consciously or otherwise, a distancing by a dominant institutional apparatus from an imagined 'Other', an 'Other' that represents anything but the Anglo-European heritage of the country. This process of 
'Othering' even manages to conflate the indigenous Maori with non-AngloEuropean migrants.

The discursive distancing creates a blind spot for policy makers, which prevents reflexivity and responsiveness to address development concerns in any meaningful way. In an insightful analysis of 'inequality, ecojustice, and ecological rationality', Plumwood offers the concept of 'remoteness', which 'dissociate[s] decision-makers very strongly from consequent ecological damage and which can distort decision-makers' knowledge of and motivation to correct that damage'. Remoteness manifests in a society's 'incapacity to heed speech' or signals from humans and non-human nature, and Plumwood argues that this is particularly evident in the context of global capitalism:

Global market-based distributive systems augment these cultural systems in making a close association between vulnerable and abused places and vulnerable and abused pcople [...] The present form of the global market economy [...] actually encourage[s] remoteness as a form of comparative advantage [...] Inequality, whether inside the nation or out of it, is a major sponsor of remoteness, especially where it creates systematic opportunities and motivations to shift ecological ills onto others rather than to prevent their generation in the first place. ${ }^{81}$

The indicators of socioeconomic deprivation, a neoliberal market-driven economic policy spurred by a commitment to short-term growth, and the consequent rapid deterioration of environmental standards in New Zealand are all the hallmarks of a crisis of development. The ideological commitment in New Zealand to global capitalism manifests itself in a distancing from any perceived association with the 'Third World'. The anxiety, both economic and cultural, to maintain a 'First World' identity, in turn keeps it from confronting the realities of the problems of growing inequality and impoverished communities. It is this anxiety that leads to a refusal in the country to acknowledge that a skewed development project only ensures that benefits stay in the hands of the few while the harms are distributed among the many.

\section{Notes}

We thank Susanne Schech and anonymous reviewers for their constructive leedback on the first submitled version of this article. We also thank Graeme Mackenzie for exemplary research assistance with this project; members of the University of Waikato's Department of Management Communication research syndicate for their comments and suggestions on an earlier draft of the paper; the Faculty of Arts and Social Sciences, University of Waikato, for a research grant that facilitaled work on this project; and the Royal Society of New Zeatand for a Marsden Grant on a larger project on Sustainable Citizenship.

1 B Gould, 'We'll never be no 1 with a bullet', Nev: Zealand Herald, 14 June 2011, at hilp:// www.nzherald.co.nz/opinion/news/article.cfm?c_id $=466$ \&objectid- 10732023 .

2 D Munshi \& PA Kurian, Migrants, genes, and socioscientific phobias: charting the fear of the "Third World" tatg in discourses of development in New Zealand', in K-K Bhatvnani, J Foran, PA Kurian \& D Munshi (eds), On the Edges of Development: Culntral Interventions, Routledge: New York, 2009, p 95.

3 PA Kurian \& D Munshi, "Tense borders: culture, identity and anxiety in New Zealand's interwedving discourses of immigration and genetic modification', Cultural Politics, 2(3), 2006, pp 359-380; Munshi \& Kurian, 'Migrants, genes, and socioscientific phobias'; and S Ganesh \& TE Zorn, 'Running the race: competition discourse and broadband growth in Aotearod/New Zealand', Media, Culture \& Society 33(5), 2011. pp 725-742. 


\section{DEVELOPMENT PERSPECTIVES FROM THE ANTIPODES}

4 I Habermas, The Structural Transformation of the Public Sphere: An Inquiry into a Category of Bourgeois Society, Cambridge, MA: MIT Press, 1989.

5 EC Hynds, 'Editors at most US dailies see vital roles for editorial page', Journalism Quarterly, 7I(3), 1994, pp 573 582; and KW Jorgensen, 'Understanding the conditions for public discourse: four rules for selecting letters to the editor', Journalism Studies, 3(1), 2002, pp 69-81.

$6 \mathrm{~N}$ Young, "Working the fringes: the role of letters to the editor in advancing non-standard media narratives about climate change', Public Understanding of Science, 2011, doi: 10.1177/ 0963662511414983.

7 Munshi \& Kurian, 'Migrants, genes and socio-scientific phobias'.

8 MT Berger. 'After the Third World? History, destiny, and the fate of Third Worldism', Third World Quarterly, 25(1), 2004, pp 9-39.

9 See, for example, R Desai, "From national bourgeoisie to rogues, failures and bullies: 21 st century imperialism and the unravelling of the 'Third World', Third World Quarterly, 25(1), 2004, pp 169 185; and A Dirlik, 'Spectres of the Third World: global modernity and the end of the three worlds', Third World Quarterly, 25(1), 2004, pp 131-148. See also Sidaway, who argues that categories such as 'developed' and 'Third World' are no longer relevant today in the context of the global financial crisis of 2008 and the exacerbated racial and class divides and economic deprivation within wealthy countries such as the USA. JD Sidaway, 'Geographies of development: new maps, new visions?', The' Professional Geographer, 64(2), 2012, pp 1-14.

10 MJ Saldaña-Portillo, The Revolutionary Imagination in the Americas and the Age of Development, Durham. NC: Duke University Press, 2003; and I Wallerstein, After Liberalism, New York: New Press, 1995.

11 Wallerstein, After Liberalism, p 109.

$12 \mathrm{U}$ Kothari, "The time of development: enduring poverty amidst rapid change', keynote address, International Expert Symposium on 'Development in the Antipodes', Flinders University, 20 21 September 2010.

13 Dirlik, 'Spectres of the Third World'.

$14 \mathrm{Ibid}$; and CE Pletsch, 'The three worlds, or the division of social scientific labour, circa 1950-1975", Comparative Studies in Society and History, 23(4), 1981, pp 571-572.

I5 Dirlik, 'Spectres of the Third World', p 133.

16 D Munshi \& PA Kurian, 'Imperializing spin cycles: a postcolonial look at public relations, greenwashing, and the separation of publics', Public Relations Review, 31, 2005, p 514; and Munshi \& Kurian, 'Migrants, genes, and socio-scientific phobias', p 96.

17 S Saul, 'The hares, the hounds, and the African National Congress: on joining the Third World in postapartheid South Africa', Third World Quarterly, 25(1), 2004, p 75.

18 A Escobar, Encountering Development: The Making and Unmaking of the Third World, Princeton, NJ: Princeton University Press, 1995, p 9.

19 Munshi \& Kurian, 'Migrants, genes, and socio-scientific phobias'.

20 Ganesh \& Zom, "Running the race".

$21 \mathrm{~J}$ Key, 'Building our future: budget 2011', Key Notes, 20 May 2011, at http://www.johnkey.co.nz. archives/1219-Building-our-future-Budget-2011.html.

$22 \mathrm{~K}$ du Fresne, 'Economy crucial to this election'. Manawatu Standard, 17 September 2008, at hitp:// www.knowledge-basket.co.nz.ezproxy.waikato.ac.nz/search/doc_view.php?d57 =flx03/text/2008/09/ 19/doc00124.html.

$23 \mathrm{PF}$ Johnsen, 'It's all gloom', Letter to the Editor, The Press, 13 August 2008, at http://www. knowledge-basket.co.nz.ezproxy.waikato.ac.nz/search/doc_view.php?d129=flx03/text/2008/08/15/doc 00365.html.

24 R Bryan, 'Teachers know best', Letter to the Editor, Dominion Post, 13 May 2010, at http:/www. knowledge-basket.co.nz.ezproxy.waikato.ac.nz/search/doc_view.php?d52 =ffx03/text/2010/05/25/doc $00035 . \mathrm{html}$.

25 Editorial, 'A safer environment', Nelson Mail, 5 June 2009, at http:/www.knowledge-basket.co.nz. ezproxy.waikato.ac.nz/search/doc_view.php?d25=ffx03/text/2009/06/09/doc00326.html.

26 A Dick, 'Letters to the Editor', $\bar{S}$ unday Star Times, 4 June 2006, at http://www.knowledge-basket. co.nz.ezproxy.waikato.ac.nz/search/doc view.php?d $78=\mathrm{fx} 03 / \mathrm{text} / 2006 / 06 / 08 / \mathrm{doc} 00481 . \mathrm{html}$.

$27 \mathrm{It}$ is worth noting that the OECD also serves as an external arbiter, and its use of 'league tables' to evaluate the performance of member states is in keeping with the theme of the 'competition state'. Wo thank a reviewer for pointing this out.

28 'Think big get rid of the lot of them', Comment, Taranaki Daily News, 28 April 2011, at http: www. knowledge-basket.co.nz.ezproxy.waikato.ac.nz/search/doc_view.php?d6 - ffxo3/text/2011/04/28/ 0009 136277 122-CB.html

29 A Slater, 'We're on the road to Third World status', Timaru Herald, 19 April 2011, at http:/www. knowledge-basket.co.nz.ezproxy.waikato.ac.nz/search/doc_view.php?d27 =ffx03/text/2011/04/19/0007 133826836-BW.html. 
$30 \mathrm{~W}$ Peters, Speech at the New Zealand First Convention, reported by Scoop Independent News, I November 2010, at http://www.knowledge-baskel.co.nz.ezproxy.waikato.ac.nz/search/doc_view. php?d68 -scoop/text/2010/11/01/PO1011-S00002.html.

$31 \mathrm{M}$ Plimmer, Letter to the Editor, Manawatu Standard, 20 June 2007, at hitp:/www.knowledgebasket.co.nz.ezproxy.waikato.ac.nz/search/doc_view.php"d50 ffx03/text/2007/06/22/doc00]47.html.

32 M Thomas, quoted in Scoop Independent News, 27 April 201!, at http:/www.knowledge-basket. co.nz.ezproxy.waikato.ac.nz/search/doc_view.php?d2 =scoop/text/20I1/04/28/PO/104-S00346.html.

33 M McCarten. 'Sorry folks, but cancer won't be shutting me up', New' Zealand Herald, 5 Septenber 2006, at htip:/www.knowledge-basket.co.nz.ezproxy.waikato.ac.nz/search/doc_view.php"d43=nzh02/ text/2010/09/05/SUN-mccarten05.htmi.

34 Kurian \& Munshi, 'Tense borders'; and Munshi \& Kurian. 'Migrants. genes, and socioscientific phobias".

35 Ministry of Health, Tatau Kahukura: Maori Healh Chart Book 20/0. Wellington, p 16, at http://www. marihealth.govi.nz/moh.nsi/pagesml/10!36/\$File/maori-hth-cbk-2010.pdf, alceessed 17 May 2011.

36 D Brash, 'Full letter to Prime Minister', 3 New's, 13 May 201 l, at http:/www.3news.co.nz/Don-Brashto-PM-John-Key-lull-letter/tabid/423/articlel D/2! I()02/Defaultalspx.

$37 \mathrm{H}$ Gillings, Wuikato Times, 14 January $20 \mathrm{ll}$, at http://www.knowledge-basket.co.nz.ezproxy.waikato. ac.nz/scarch/doc_view.php?d190:=-17x03/text/201 1/01/14/0006133253619-BC.html.

38 L Hardgrave, Letter to the Editor, Taranaki Daily News, 1 Seplember 2008, at http://www.knowledgebasket.co.nz.ezproxy_waikato.ac.nz/search/doc_view.php?d84=ffx03/text/2008/09/02/doc00177.html.

39 D Munshi, "Media, politics, and the Asianisation of a polarised immigration debate", Australian Journal of Communication, 25(1), 1998, pp 97-110; P Spoonley \& A Trlin, "Immigration, immigrants. and the media: making sense of multicultural New Zealand, paper produced as part of the New Settlers Programme Project, Malssey University, Palmerston North, at htip://masseynews.massey.ac.nz/2004/Clippings/Immigration-paper-July-04.doc; and Munshi \& Kurian, 'Migrants, genes, and socioscientific phobias'.

40 Munshi \& Kurian, 'Migrants, genes, and socioscientific phobias'.

4] C. Ward \& A Masgoret, 'Discrimination against immigrants seeking employment: fact or fiction?', paper presented at the Annual Meeting of the New Zealand Psychological Society, Wellington, 2004.

42 R Jordan, Letter to the Editor, Bay of Plenty Times, 21 April 2008, at http://www.knowledge-basket. co.nz.ez.proxy.waikato.ac.nz/sestrch/doc_view.php?d56=nzh02/text/2008/04/22/BOP-2I LETTERSMM. html.

$43 \mathrm{~J}$ While, 'Take your pick of lile's leliovers', North Shore Times, I Seplember 2006, at http:/ www. knowledge-batskel.co.n7.ezproxy.waikato.ac.nz/search/doc_view.php?d20:=fixstuft/text/2003/STF/09/ $02,052507 / \mathrm{doc} 00041$.html.

44 Munshi \& Kurian, 'Migrants, genes, and socioscientific phobias'.

45 J Buckland, 'Race lor Auckland', Letter to the Edilor, Sunday Star Times, 4 July 2010, at http://www. knowledge-basket.co.nz.ezproxy.waikato.ac.nz/search/doc_view.php?d22-ftx03/text/2010/07/04/A011 127776560-CL.html. See also B Rudman, 'Mayor suffers racial relapse', New Zealand Herald, 23 June 2003, at htp:/www.knowledge-basket.co.nz.ezproxy.waikato.ac.nz/search/doc_view.php?dl $=n$ zho2/ text/2003/06/23/20030623nzh3508747.html.

46 L Laird, "Feral" attack on Far North Maori can't rufle MPs", Northern Advocate, 25 May 2010. at http:/www.knowledge-basket.co.nz.ezproxy.waikato.ac.nz/search/doc_view.php"d33 -nzh02/text/ 2010/05/26/NAD-25-Laws.html.

47 A Harlevelt, "Third World tag upsets village supporters", Daily Post, 8 February 2010, at http://www. knowledge-basket.co.nz.ezproxy.waikato.ac.nz/search/doc_view.php?d38=nzh02/text/2010/02/09/ ROT-08whaka.html.

48 A Caspari. "Car window washers killing my business": charges laid amid claims of drug ase and scaring people at city centre". Daily Post, 2 February 2010, at http://www.knowledge-basket.co.nz.ez proxy.waikato.ac.nz/search/doc_view.php?d40=nzh02/text/2008/10/03/ROT-02PILEAD.html.

49 RE Stone, Letters, Waikato Times, 10 October 2006, at http://www.knowledge-basket.co.nz.ezproxy. waikalo.ac.nz/search/doc_view.plpp'd37=ffx03/text/2006/10/14/doc00312.html.

50 Children's Commissioner, "About child poverty", 2010. at http://www.oce.org.nz/home/chiklpoverty/ about_child_poveriy.

51 K Chapman, 'Our kid care doesn't rale', 14 August 2011, Scoop, at http:/www.stuff.co.nz/national/ $5441231 /$ Our-kid-care-doesn-l-rate.

52 UN Women New Zealand, Press Release, 26 July 2011 , at ht1p:/www. unifem.org.nz/? $\cdots 538$.

53 S St John \& D Wynd (eds), Left Behind: How Social and Income Inequalities Damage New Tealand Children, cpag.org.nz, 2008, at http://www.cpag.org.nz/assets/Publications/LB.pdi.

$54 \mathrm{~J}$ Brown, speech reported by Radio New Zealand Newswire, 3 December 2009, at http://www. knowledge-basket.co.nz.ezproxy.waikato.ac.nz/search/doc_view.php?d74-..rnzdb/text/2009/12/03/3d7 ()e 46 b.h1ml. 


\section{DEVELOPMENT PERSPECTIVES FROM THE ANTIPODES}

55 M Turei, parliamentary address reported by Scoop Independent News, 8 February 2011, at http:// www.knowledge-basket.co.nz.ezproxy.waikato.ac.nz/search/doc_view.php?d145=scoop/text/2011/02/ 08/PA1102-S00106.html.

56 Editorial, 'A safer environment', Nelson Mail, 5 June 2009, at http://www.knowledge-basket.co.nz.ez proxy.waikato.ac.nz/search/doc_view.php?d25=ffx03/text/2009/06/09/doc00326.html.

57 R Hill, 'Desperate wait for cancer treatment', Dominion Post, 29 September 2007, at http:/www. knowledge-basket.co.nz.ezproxy.waikato.ac.nz/search/doc_view.php?d73 $=\mathrm{ffx} 03 / \mathrm{text} / 2007 / 10 / 02 / \mathrm{doc}$ 00103.html.

58 SJ Simpson, Letter to the Editor, Bay of Plenty Times, 13 September 2008, at http://www.knowledgebasket.co.nz.ezproxy.waikato.ac.nz/search/doc_view.php?d63 nnzh02/text/2008/09/14/BOP-LETEX1. htinl.

59 G Taylor, 'Taskforce report: green economy study more use', New Zealand Herald, 7 December 2009, at http://www.knowledge-basket.co.nz.ezproxy.waikato.ac.nz/search/doc_view.php?d68-nzh()2/text/ 2009/12/07/NZH-taylor07.html.

60 S McLeod, Letters to the Editor, Northern Advocate, I November 2008, at http://www.knowledgebasket.co.nz.ezproxy.waikato.ac.nz/search/doc_view.php?d197=nzh02/text/2008/11/02/NAD-LETTE: RSO1.html.

61 D Williams, 'Dairy lifts SI emissions', The Press, I July 2010, at http://www.stuff.co.nz/environment/ 3872450/Dairy-lifts-SI-emissions.

$62 \mathrm{~T}$ Wayne, 'New method to modify genes will change attitude', Waikato Times, 23 October 2007, at http://www.knowledge-basket.co.nz.ezproxy.waikato.ac.nz/search/doc_view.php'?d44 _..ffx03/text/ 2007/11/05/doc00079.html.

63 'Disgust at "Third World" litter problem', Timaru Herald. 21 January 2009, at http://www.stuff.co.nz/ timaru-herald/803874/Disgust-at-Third-World-litter-problem.

64 B Torrie. 'Big stink over ugly depots', Manawatu Standard, 24 October 2008, at http:/www. knowledge-basket.co.nz.ezproxy.waikato.ac.nz/search/doc_view.php?dl6 =-ffx03/text/2008/10/28/doc 00010.html.

$65 \mathrm{~J}$ Cadacio, 'Takapuna Beach is a mess', North Shore Times, 28 August 2008, at http://www.knowledgebasket.co.nz.ezproxy.waikato.ac.nz/search/doc_view.php?d94 wfixstuff/text/2003/STF/08/28/052512/ doc00035.html.

66 'Sustainability starts at home', Daily Post, 12 February 2008, at http://www.knowledge-basket.co.nz. ezproxy.waikato.ac.nz/search/doc_view.php?d55=nzh02/text/2008/02/13/ROT-12BIZSWAP.html.

$67 \mathrm{~J}$ True \& C Gao, 'National identity in a global economy', in R Miller (ed), New Zealand Government and Politics, Auckland: Oxford University Press, 2010, p 43.

68 Tourism New Zealand, "Tourism New Zealand unveils "100\% pure you", 2011, at http://www tourismnewzealand.com/news-and-features/latest-news/2011/01/tourism-new-zealand-unveils-100-per cent-pure-you/.

69 M Joy, "The dying myth of a clean green Aotearoa', New Zealand Herald, 25 April 2011, at http:// www.nzherald.co.nz/nz/news/article.cfm?c id =1\&objectid $=10721337$.

70 Editorial, '100\% Pure as true a slogan as it ever was', New Zealand Herald, 20 June 2011, at http:/ www.nzherald.co.nz/business/news/article.cfm?c_id =3\&objectid $=10733250$.

71 Munshi \& Kurian, "Migrants, genes, and socioscientific phobias"; and Ganesh \& Zorn, 'Running the race'.

72 Kurian \& Munshi, "Tense borders".

73 P Skilling, 'National identity in a diverse society', in R Miller (ed), New Zealand Govermment and Politics, Auckland: Oxford University Press, 2010, p 61.

$74 \mathrm{Ibid}, \mathrm{p} 58$.

75 True \& Gao, 'National identity in a global economy', p 42.

76 lbid, p 49

77 Our use of the term 'distancing' is distinct from Princen's, who uses the term to refer to the insulation of consumers from the consequences of their consumption decisions in a commodity chain. T Princen, 'Distancing: consumption and the severing of feedback', in T Princen, M Maniates \& $\mathrm{K}$ Conca, Confronting Consumption, Cambridge, MA: MIT Press, 2002, pp 103-131.

78 H Rittel \& M Webber, 'Dilemmas in a general theory of planning', Policy Sciences, 4, 1973, pp 155-169, at $\mathrm{http}: /$ www.uctc.net/mwebber/Rittel+Webber+Dilemmas+General_Theory_of_Planning. pdf.

79 P Gibbons, 'The far side of the search for identity: reconsidering New Zealand history', New Zealand Joumal of History, 37(1), 2003, p 39.

80 Skilling, 'National identity in a diverse society', p 55.

81 V Plumwood, 'Inequality, ecojustice, and ecological rationality', in J Dryzek \& D Schlosberg (eds), Debating the Earth: The Environmental Politics Reader, Oxford: Oxford University Press, 2005, p 617 . 


\section{Notes on contributors}

Priya A Kurian is Associate Professor of Political Science and Public Policy at the University of Waikato. Her research interests straddle the areas of development studies, environmental studies, and science and technology studies, with particular focus on race and gender. She is author of Engendering the Environment? Gender in the World Bank's Environmental Policies (2000), and co-editor of International Organizations and Environmental Policy (1995), Feminist Futures: Re-imagining Women, Culture and Development (2003) and On the Edges of Development: Cultural Interventions (2009). She is currently Co-Principal Investigator (with Debashish Munshi) of a project on 'Sustainable Citizenship' funded by the Royal Society of New Zealand's Marsden grant.

Debashish Munshi is Associate Professor of Management Communication at the University of Waikato. His research focuses on issues of diversity across the fields of organisational communication, public relations, development studies, and science and technology studies. He is co-author of Reconfiguring Public Relations: Ecology, Equity, and Enterprise (2007), and co-editor of On the Edges of Development: Cultural Interventions (2009), and The Handbook of Communication Ethics (2011). He is currently Co-Principal Investigator (with Priya Kurian) of a project on 'Sustainable Citizenship' funded by the Royal Society of New Zealand's Marsden grant. 